\title{
23. Fridays For Future - FFF Europe and beyond
}

\author{
Anuna De Wever Van der Heyden, Luisa \\ Neubauer and Katrien van der Heyden
}

\section{KICK-OFF BY GRETA THUNBERG}

The Fridays For Future movement (FFF) was started in August 2018 by Greta Thunberg, the (then) 15-year-old high school student from Sweden who decided on a message and an action that was so ingenious and, at the same time, simple, that it spread around the world and brought together many climate organizations on all continents.

The message Greta started spreading was intriguing: 'Why should I study for a future, that soon will be no more?' The subsequent demand was just as straightforward - all governments should be in line with the Paris Agreement on climate change (halve global $\mathrm{CO}_{2}$ emissions by 2030 and to just below zero by 2050). It is the one central demand of the movement.

The main target groups Greta wanted to convey her message to were twofold. On the one side, she addresses policy-makers and politicians, whom she urges to act. On the other side, she asks all other individuals and economic leaders in society to join her protest. Greta realized that the message about rising $\mathrm{CO}_{2}$ levels had been spread for decades, but that apparently no one was listening. She realized this had to be repeated, but differently. So, Greta chose to challenge leaders everywhere by confronting them with the following two paradoxes: (1) 'Why do you want me to go to school if scientists are clear that we won't have a future due to climate change disasters that will lead to the collapse of our societies?'; (2) 'Why do you want me to study sciences if you do not listen to what scientists have to say?' Indeed, this is a reformulation of the matter from the perspective of young people who have their future ahead of them and it brilliantly exposes the 'Catch-22' situation these young people are in. It literally throws back the challenge they face at the feet of the generations that caused it.

Greta decided to bring this message to the policy-makers by sitting in front of the Swedish Parliament one day a week - every Friday (hence Fridays For 
Future) - until her country was in line with the Paris Agreement. She started doing this in September 2018 and she has continued her protest in the same way ever since.

Parliaments tend to be 'neutral' places where no demonstrations are allowed. For Greta this meant a bit of a challenge before her occupation of her corner close to the Parliament every Friday was accepted. She has a guest book to accommodate the many visitors passing by, but never hoped that it would amount to much more than that. At first she did not endeavour to call on other young people to join her; that was a step taken by her followers in other European countries, most notably Germany, Belgium and the UK, but later on also France, Italy, the Netherlands and Eastern European countries. A common feature embedded into most of the youth climate activists' vision is that they are not thinking about the consequences of failure - they just start. They are willing to do 'the walk of shame' should their actions amount to nothing.

It did not take very long before the 'Greta story' started to spread on social media and soon it was picked up by other students around the globe. There had been some actions in Australia, and in Germany Luisa Neubauer started to organize the Fridays For Future demonstrations. Then other countries followed and one of the most amazing cases with regard to scale and amplitude was Belgium.

\section{THE BELGIAN CASE OF FRIDAYS FOR FUTURE - YOUTH FOR CLIMATE}

To illustrate the depth and breadth of the students' actions, we will now turn to the case study of Belgium.

Interestingly, despite the FFF movement becoming very popular all over the world, sharing the one common demand - to be in line with the Paris Agreement - the start of the action in each specific country seems also to be influenced by the local politics of the country where it takes shape. In the case of Belgium, there was a huge climate demonstration mid-December 2018 to pressure the Belgian government before it attended the COP (Conference of the Parties) climate meeting in Katowice, Poland. Estimates of participants in this demonstration ranged between 65000 and 75000 . This is huge, given the fact that the Belgian population is only around 11 million.

Then, one week later, the Belgian political delegation came back empty-handed. Belgium was one of the few countries in Europe not to sign the agreement and the delegation even left before the COP was finished. This context is important, as the students starting the school strikes in Belgium (Anuna De Wever Van der Heyden and Kyra Gantois), began their actions because they were offended by the lack of democratic consciousness the politicians showed as they completely ignored the voices of so many people by 
not signing the COP agreement. The political arrogance that was demonstrated - one minister even flew there in a private jet, one of the most environmentally unfriendly ways of travelling - by ignoring the demonstration was the trigger to get the Belgian school strike movement going.

The origin of the school strikes in Belgium is not just the fear of students about the warming climate, as much as the worries about a failing government. The urgently felt need for people to step in and save democratic values motivated them as much as anything else to take to the streets. There is discrepancy in the Belgian case on climate policy. This country has the highest number of climate change measures of all European countries (around 150) but ranks almost lowest on results. This discrepancy can only be understood by taking a closer look at the Belgian political system.

Indeed, the Belgian governmental system had been in deadlock for decades with a complicated system of regional, federal and community governments, all producing an energy, environment and a transport minister, which had resulted in a 'Kafkaesque' battle and a bureaucratic nightmare where in the end nobody was satisfied with the climate policy. A political proverb in Belgium says: 'In Belgium every minister claims the competence, but none are responsible'.

The joint group of environment, energy and transport ministers were supposed to construct one comprehensive climate action plan, but even that task had not been accomplished by the end of the legislature in December 2018. This lack of political response on the matter led to the shameful fact that Belgium - among the top European countries in economic terms - was on the last but one spot in the European ranking on climate change results.

It is precisely this discrepancy between the worrying scientific information young people like Greta and Anuna get in schools on the one hand and the utter ignorance they witness among their governments in dealing with this, that motivates them to take a fearless stance. The word fearless is used very consciously here, meaning a non-aggressive way of challenging the powers that be by exposing their charade rather than attacking them violently. The tale of the Emperor's clothes has been mentioned in this context as well. It is not uncommon for a younger generation to step up and challenge the order of things. However, what makes the climate actions a unique case is the very young age of its leaders and their sex and gender.

Obviously, we've had female leaders before in many movements, but that would typically only be in women's movements. Even in labour movements, where we have wonderful examples of women taking prominent roles, quite often it was in a broader movement where men had the final say. Not here. Young girls build context, construct vision, theories and strategies, mobilize for actions and are the frontline figures. 
In a conversation, ${ }^{1}$ Greta Thunberg expressed it as follows: 'Boys run ever forward in a worldwide rat race, competing with each other. Girls will never win that race; we don't even want to be part of it. Girls have the ability to take a step back and contemplate about where they want to go. This wider vision is needed to see the broad picture of what is really going on in the world'. As such, this is also a shift in the definition of what it means to be a leader. In a world where leadership positions are typically shaped by hyper-masculine stereotypes, these young female leaders redefine the concept of power. They turn it around from being dominant into being serving and caring.

There is another innovative trend to be watched in this movement: their young age. Anuna - the leading figure in the Belgian case - took to the streets the moment she realized that the next elections were in May 2019, where she would not have the right to vote yet because she only turned 18 in June 2019. She would not have a chance to weigh in on the next legislation, which will be the last legislation that can possibly make a shift in time to curb climate change. This feeling of utter injustice - that the fate of the future generations is decided by the older generations alone - has been a huge motivator for high school students to take to the streets.

It is also interesting to see how they feel inspired by other civil movements, most of all the black liberation rights movement in the US. Anuna regularly cites examples of public disobedience actions like Rosa Parks refusing to give up her seat on the bus. The school strikes want to bring home the same message of doing something inspiring and non-violent that challenges the system by being disobedient in a provocative, publicly visible way.

Indeed, the Belgian school system was at a loss when three weeks into the school strikes, 35000 high school students left their classes and took a train to Brussels to protest. Even after six months, the educational policy-makers had not come up with a comprehensive plan on how to respond. Each school board had to decide individually on how to respond. On average, private Catholic schools were a lot harsher in their sanctions than public schools - for example, some pupils receiving 0 on every test missed on a school strike day and teachers deliberately planning as many tests as possible during such days. In other schools, students were allowed to catch up on missed tests on other days. Other schools even supported the strikes and sometimes even teachers went along with their pupils to Brussels.

It was not only schools that had a hard time dealing with the striking students. There was a huge evolution in how the politicians responded too. At first it was deemed 'cute'. A word often heard during the first weeks, but one that has a double-bind message: 'Yes, it is nice that young people want to do something for the climate but let's not take this too seriously'.

This radically changed in Belgium when - around six weeks into the strikes - the Flemish environment minister, Joke Schauwvliege, had to resign. It was 
clear that after the 'cute' phase, she had started to feel increasingly uncomfortable about the movement, which voiced outright criticism of all policy measures she took. She had made the tactical mistake of claiming in the beginning that she felt that the students supported her policies and measures, only to be answered on the next strike by hundreds of slogans that ridiculed her. Next she made an even bigger mistake by claiming in a speech that the school strike movement was actually a conspiracy against her, supposedly confirmed by the state security agency. This announcement immediately made the headlines. No wonder, as this was a very serious allegation against minors. When the state security agency announced there was no such investigation or conspiracy and that there had never been a communication about this with the minister, she had to resign within 24 hours.

This also marked the moment when politicians started to take the students seriously. The tone in their communication turned from 'cute' and 'heroes' to 'fearmongers' or 'neurotics'. Indeed, that is the moment the political parties took sides, with the political left proclaiming the school striking youth were heroes, and the right political spectrum describing them as blind radicals, kids with neurotic panic attacks or doomsday preachers. One of the most frustrating and unfortunate outcomes of the school strike movement was this political split. All over Europe we see the old left and right dichotomy tearing communities and families apart over issues like migrants and refugees, women's rights and economic systems. The Belgian youth that started the movement were well aware of this trap. Once caught in the left or right hegemonic block, the same old mechanisms of political power struggles would capture the energy and divert it towards fighting the other block, instead of connecting people across generations, political opinions, race, gender, to fight for a common goal to save humanity.

Anuna De Wever Van der Heyden - the Belgian spokesperson of the movement - kept on repeating in each interview that she wanted to unite rather than divide. Climate should not have a political colour because it concerns every single person and humanity as a whole. It is clear by now that such a message is countering any institutional logic built into political systems of countries dominated by a 'particracy' instead of a 'democracy'. This is but an illustration of a point made earlier that the youth were as much aware of the institutional and political crisis in our democracy as they are aware of the climate crisis. Nevertheless, despite chronic attempts to the contrary, the political level continued to push the movement into the left side of the playing field.

\section{THE GERMAN CASE FOR FRIDAYS FOR FUTURE}

In Germany, the publicly most well-known figure in Fridays For Future is Luisa Neubauer. Luisa had been a climate activist for quite some time and had, 
rather coincidentally, met Greta Thunberg in Katowice in December 2018. Impressed by Greta's message and her way of conveying it, she decided to start the same type of action in Germany to enlarge the impact of the school strikes. So, upon returning to Germany after the climate conference in Katowice, Luisa - back then a university student - started climate school and university strikes in front of the Bundestag in Berlin.

Similar to the Belgium case, in Germany too the momentum was decisive. There was a 'vibe' already in Germany about the climate. Not only had the European heatwave in the summer of 2018 had an unprecedented impact on German agriculture and industry (for several weeks, ships weren't able to carry goods on the Rhine as the water level was historically low), but also, Germany was in the middle of a debate over a so-called coal exit while the government had just announced it would miss its 2020 emission targets. Not surprisingly, Luisa was not the only one who felt irritated by the lack of drastically needed political climate action. Hence, she quickly got in touch with others who had the same idea. They reinforced each other to get the strikes going in other cities as well. On the first Germany-wide \#FridaysForFuture climate strike on 14 December 2018, there were strikes going on in 14 different cities.

After this first day of strikes, the movement grew exponentially. The key mobilization and organization of the climate strikes happened online, via WhatsApp. Links to the WhatsApp group were shared widely and uploaded on a website to make it as easy as possible for people to join and to stay in the loop. As such it was very organic in its origin, not specifically planned, but catching up on the vibe that was already there.

Deriving from the first handful of people who coordinated similar strike actions on the same Friday in a different city, a decentralized movement structure was established. The first person from a specific city or town that wanted to start striking would open up a local Fridays For Future chapter by simply creating a WhatsApp group and spreading the link to the group. Almost organically, a democratic structure was established: each chapter would send one delegate to the weekly telephone conference where decisions were made democratically, with each chapter having one vote in a majority vote.

This is different from the Belgian case where in the first six months the core team took all decisions. The German model was more democratic. Easy online access to the movement, low participation barriers and the possibility to have a say on all decisions attracted an enormous number of organizers. One month after the first strike in December, the number of cities where a strike was organized grew from 14 to 55 . More than four months later the organizers met for the first time in real life.

There were notable spillover effects from other countries that shaped the German Fridays For Future movement. In Germany, FFF was inspired, for example, by the initiatives that the Belgians took to call on the scientists to 
write up a climate plan. So, in Germany, Luisa and others reached out to scientists to support FFF - only to find out that hundreds of scientists had already started to get together as 'ScientistsForFuture'. In March 2019, more than 20000 scientists had signed a support paper for Fridays For Future.

The strikes happened primarily in political spaces - near town halls, ministries and parliaments. Throughout the year 2019, however, protests were also organized in front of coal plants (in the Rhine area) and in front of the European Commission building (Brussels) in the week before the elections of the European Parliament. The German FFF activists later also travelled to Romania by bus to meet the European heads of state who had gathered there for a meeting to determine the agenda for the next EU legislation. During the summer of 2019, they attended the European climate youth conference in Lausanne and organized an international strike in Aachen where youth from more than ten countries were invited to unite.

The main challenge was to keep people motivated for a cause that seems hopeless as the reaction of the politicians was not what they had hoped for. Yes indeed, most politicians in Germany wanted to talk but claimed at the same time that a lot had already been done to avert climate change. Three common answers given when strikers challenged decision makers where that:

- a lot had been done in the past;

- more ambitious climate action was not politically feasible as jobs and economic growth had to be secured while Germany was also the only country in the world that had plans to phase out both nuclear and coal energy;

- that it was up to China, the US and India to act, as German emissions in 2019 would only add up to 2 per cent of global emissions.

However, as the climate targets in Germany had been missed in the past, and those for the future were not even in line with the Paris Agreement and the concerns for equity, the gap between the expectations of the young people and the political will to take further steps remained wide open.

The support the climate striking youth received from the general public was rather positive about the initiatives at first and remained strong among certain people, while others dropped out. The young people were praised initially for their engagement in trying to solve the crisis. However, as time went on and nothing was really achieved on a political level, a climate-tiredness settled in and the emotional support towards the movement became rather ambivalent. It is now clear that the current environment is much more polarized (both in Germany and Belgium) and people are now all fervently for or against, with hardly any middle ground left. The strategy to deal with this polarized environment is straightforward: stick to the key messages, try as hard as possible to 
not get lost in the nitty-gritty of climate politics, and bear in mind that science is behind the movement.

The strength of the German network is, first, ownership. People can join in the decisions, they feel involved, so even if people don't have much time, they feel part of the movement and join every Friday. The second notable strength is the size of the movement. From a certain point onwards, the 'climate kids' were so many, they have started framing the perception of an entire generation. They are widely considered the 'cool kids' - attracting more and more young and, increasingly, older people to join the club.

\section{COMMON THREATS AND CHALLENGES OF THE CLIMATE SCHOOL STRIKE MOVEMENT}

\section{Online Threats and Hate}

There is a paradoxical situation that the school strike movement would never have grown this big in such a short time span without the use of social media. It is a well-known fact that it can 'make or break' people and movements. So, just as the political spectrum has been split with an ever-widening gap in the middle, the same holds true of any social media platform.

Right from the very start (organized) campaigns started to troll the frontline persons of the movement. Greta herself has been painfully and chronically hit by trolls, not even shying away from ridiculing her autism spectrum disorder, but also the spokespersons in each European country (Anuna in Belgium, Luisa Neubauer in Germany, etc.) have been trolled relentlessly by any means possible. Anuna, for example, received hate messages and threats via Facebook, on websites, through e-mail and posted letters, Instagram, WhatsApp, Messenger, and so on.

However, despite the diversity in the means of communication used by the trolls, the content of the trolling messages is surprisingly homogeneous. Interestingly enough, hardly any troll message contains opinions about climate change. It is the elephant in the room, trolls do not want to get into it (since obviously with all the scientific back-up, it would be an argument hard to win). Instead, there is a huge amount of gender-based harassment going on. In the case of Anuna (who is an outspoken member of the LGTBQI ${ }^{2}$ community as well, being gender-fluid and having a lesbian relationship) she received a worrying number of messages from men who wanted to rape her to 'cure' her homosexuality. In an all-time low attempt at intimidating her, she received the following message: 'Just wait until she gets a Nigger Dick into her pussy, then she'll know she's a woman'. ' $\mathrm{CO}_{2}$ prostitute' was another favourite name to call her. When trolls found out that Anuna had an identical twin sister they 
proclaimed: 'So, now we need to get a double-barrelled gun'. Others called for a 'Flemish Breivik' to get rid of the nuisance called Anuna.

The sexual content is omnipresent in most messages and is in line with the age-old patriarchal way of intimidating women, by imposing masculine sexual violence upon them. Indeed, looking at sexuality as a means to submit women to masculine power has been an ever-popular identity marker used by most (extreme) right-wing movements. Increasing your show of disdain for women can get you up the ladder of the pecking order in toxic masculine environments and as such this shows how it is more about themselves establishing their male power pyramid than about entering into a real dialogue with the school strike students. Apparently, in some right-wing movements you can score by sexually bashing minor girls, all the more so if they are celebrities of the climate movement.

\section{Systemic Errors on a Macro Level}

Another challenge the school strike movement had was the organizational inexperience the youth showed at structuring their movement. This was a threat coming from within. Right from the start, is was clear that climate change requires a system change. Indeed, the systemic errors like the democracy crisis, the hyper-masculine stereotypes dominating leadership positions and the economic mechanisms that have slowly turned from creating welfare to pillaging the last resources we have, were all profoundly questioned by the youth taking to the streets.

As with all movements, it is not always easy to translate this new vision into the nitty-gritty of daily lives and the functioning of a grassroots movement. A first symptom of the rather chaotic way everything was organized, is the high diversity in concepts and names used. For example, while it is Greta Thunberg who coined the 'Fridays For Future (FFF)' actions, Anuna in Belgium was not yet aware of that name (FFF) when she started her school strikes, so she called them the 'Youth for Climate' actions.

Also, when it comes to the aspirations of changing the world economic system, lots of different concepts are used. 'Transition economy', 'circular economy' and 'new green deal', are used synonymously as they refer to the idea that things need to move away from a fossil fuel economy into a more ecologically sustainable model.

Another potential confusion among the school strikers was the demands of the movement. Greta Thunberg had been very clear right from the start to continuously repeat the one demand: 'be in line with the Paris Agreement'. This demand was difficult to maintain for months on end, since journalists kept on asking the students what measures needed to be taken to be in line with the Paris Agreement. Obviously, this is a potential media trap, since we 
cannot expect high school children to provide the world with expertise on climate change and scientifically tested and approved solutions. In one interview, Anuna proclaimed that as far as she was concerned, banks should print additional money to cover the climate costs. This view was ridiculed for the weeks to follow, until some expert economists actually took her side and came up with historic examples where printing money had indeed pushed societies out of a deep crisis.

To circumnavigate this media trap in her future interviews with the media Anuna and her movement then decided to call on Belgian climate scientists to organize a panel and write up an action plan of what Belgium should do to be in line with the Paris Agreement. This call was met by hundreds of scientists from all sorts of scientific fields who then spent the next months voluntarily writing this action plan, which was presented two weeks before the May elections. A unique feat in Belgian history.

In Germany, the demands evolved into a different direction, as the biggest challenge there is the closure of the remaining (brown-) coal plants. Luisa Neubauer and her movement oriented their demands to focus on the elimination of coal.

In the UK, the situation was more complex because the political crisis was even more omnipresent than elsewhere by being in gridlock over Brexit. Putting any other item on the political agenda was almost a mission impossible, but somehow the climate message also gave a feeling of relief to quite a number of people, that maybe, this might finally be an issue that can unify rather than divide the country.

\section{Systemic Errors on a Micro Level}

There were also systemic errors within the movement itself. As has been said, by the time the 'Fridays For Future' name was widely communicated, some local movements had already started with other names. This is why 'school strike movement' might be a better name for the young students' movement following in the footsteps of Greta Thunberg. But, what's in a name? Surely that has not really tempered any enthusiasm among the followers? However, the way in which their organizations - whatever the name - would and should be structured, posed a much bigger problem.

In Belgium, Anuna's team chose a more centralized approach, having a core team with members who each had a clearly defined responsibility (e.g., local strikes, communication and media, climate action plan, etc.). The core team members were in no way democratically chosen, but rather formed organically through the involvement of various young people in the movement. It seems that the most important criteria to get in the team was to be very involved and 
to get to know other team members. Obviously, this is not an ideal situation and resulted in tension between the in- and out-group.

In Germany, the approach was quite the opposite of being centrally directed. Luisa was faced with numerous local groups and teams who all wanted to have a word in the final decision. This grassroots democracy proved quite difficult when responding to political steps that needed a quick reaction in the media.

In the UK, the school strike movement went one step further and did not even want to have an official 'face' of the movement or spokesperson. While in Sweden, Belgium and Germany it was very clear that the media should turn to Greta, Anuna and Luisa respectively, this was not the case in the UK, where the endeavour to be borderline anarchistic, resulted in much confusion.

Despite none of these countries solving the institutional paradigm in a satisfactory manner, it remains an incredible feat how many young people they managed to mobilize and take to the streets. As with any organization, there is a steep learning curve and in each country the teams showed creative and innovative solutions to deal with the problems at hand in a much more pragmatic and flexible way than any adults do.

\section{POSITIONING THEMSELVES IN A WIDER SOCIAL LANDSCAPE}

Not long after Greta Thunberg started her strikes, President Macron decided to raise taxes on fuel. This led to an immediate revolt generated in some poor rural areas in France where people depend on cars as the main means of transport and face genuine poverty. They felt the environmentally friendly measure would make the poor pay for a problem they didn't create.

As such, this context provided an argument for the press to position the gilets jaunes (yellow vests) movement at loggerheads with the climate change movement. This argument only holds when looking at the superficial triggers of the movement, not when looking at the deeper-lying causes of these people taking to the streets.

The common denominator in both movements is the call for a systemic change. None of the yellow vests would mind a change towards an ecologically healthy world, as long as this does not push them even further into poverty. The same holds true for the youth of the school strike movement, who all agree that in the climate shift there needs to be social justice, hence 'climate justice'.

Despite these profound common touchpoints, the relationship between the two movements remained awkward. Mostly this might have been due to the entirely different profile of protesters (age, social class, sex, etc.), but definitely because of the different tactics chosen. The yellow vest movement was clearly aggressive and caused some damage and violence in both Paris and Brussels. In one difficult instance in Belgium, both protests were merged and 
the climate youth ended up being pushed and challenged by the yellow vests to go on a rampage through the streets. Instead, the climate youth signalled to each other to remain calm and sit down, where they stayed put -10000 of them - to give the police time to sort things out. They started to sing and, for many, these were the most powerful moments in all the demonstrations.

Never again did the school strike movement in Belgium protest together with the yellow vests. It remains to be seen how they can find a common ground in the future.

\section{EUROPE AND BEYOND}

A common argument that constantly needed answers was the reasoning that this is a worldwide problem and a small country cannot change climate change - as if this was enough reason to give up. It is an argument typically used by climate delayers. Indeed, climate change is a worldwide problem, but this does not mean that small countries cannot make a difference. The definition of small itself is problematic since it refers to the size of the territory or population, but no link is made to the actual $\mathrm{CO}_{2}$ output per head in the population. According to that last measure, some small countries become big and vice versa.

Another paradoxical fact in climate change is that, on average, the countries suffering most from the consequences (where desertification or floods take place and sea levels rise), are the ones where less $\mathrm{CO}_{2}$ is emitted. This poses the challenge of creating global solidarity at a time when even solidarity and care within one country are under enormous pressure and are being stripped down by austerity measures.

Despite this unfavourable context, social media do not know borders and the call to action from Greta Thunberg was heard on a worldwide scale. In countries all over the world, teenagers were stepping up and starting school strikes, even in countries like Russia where any opposition to the government puts anybody in real danger. By March 2019, the movement had moved well beyond the European borders. And by 15 March, a global strike was organized. More than 1.5 million young people in 2083 cities of 125 countries across the world participated. All continents were present, even Antarctica, where a team of researchers raised a global strike banner.

Another global strike was held one week before the European elections and, in the week of 20 September 2019, the next one was planned to kick off the new schoolyear and further climate actions were planned as well as a climate school strike every month throughout 2020. It is clear that young people everywhere have woken up and are not ready to go back to sleep before the issue is resolved.

In the late summer of 2019, Greta Thunberg got on a racing sailboat to cross the Atlantic to attend a UN climate meeting in New York, where she 
was invited by António Guterres, the UN Secretary-General. In the autumn of 2019, several climate youth from different European countries (amongst others, Anuna and two other members of her Belgian team) followed Greta's example by taking a sailboat across the Atlantic to attend the COP25 climate conference scheduled to take place in Santiago de Chile. However, when more than halfway through their six-week sailing journey, social riots and protests started in Chile. In these circumstances the Chilean president deemed it unsafe to host the COP25, so cancelled the event. Some days later, the event was moved to Madrid in Spain but the same dates were kept, making it impossible for Anuna to sail back in time to Madrid. Another huge disappointment for the delegation. However, Anuna and her delegation were invited to take part in an Alternative COP conveyed inside the Amazon forest, so at least that gave the satisfaction of creating a goal to the Atlantic crossing. Meanwhile, Greta had travelled through the USA and Canada giving speeches and participating at rallies all along the way. Greta did catch a racing sailboat and arrived just in time. Also, Luisa Neubauer, who was not expected to attend the COP25 in Chile because travel by sailboat would take too long, ended up taking the train from Germany to Madrid and could attend the meeting after all.

In fact, hundreds of youth climate activists from various movements ended up attending the COP25 and took several actions in and outside the event to raise awareness about the urgency to get to a good deal. However, COP25 ended without the hoped breakthrough, pushing the most important issues at stake to the COP26 meeting in Glasgow in 2021. That will be the last meeting to finalize the Paris Agreement. At the same time, during COP25, the newly appointed president of the EU, Ursula von der Leyen, together with her environment commissioner, Frans Timmermans, announced a European Green Deal. They both specifically stated in their speeches that this happened because of the youth's engagement in climate.

\section{CONCLUSIONS AND RESULTS}

It is clear that Greta Thunberg gave voice to a silent scream carried in the hearts of an entire generation of young people who saw their future being sold out to greed and short-sighted profits while neglecting the really important things in life. She struck a match that was then ignited even further by various youth all over Europe and elsewhere, like Australia, New Zealand, Kenya, Nigeria, South Africa, Uganda, and so on, who started to organize massive protests.

The informal way of communication via social media, the chaotic diversity in organizations, structures and even demands, have not posed any threat to the growth and enthusiasm this movement has generated. On the contrary, it is precisely the freedom to join and the emphasis on what connects us rather 
than what divides us, that makes the movement grow further in a more flexible and creative way.

The movement has an incredible list of results so far. Internationally, they have been able to create the biggest awareness of the climate urgency among diverse societies ever. There is literally no society where climate has not been discussed in one way or another in this past year. Also, they brought the topic home, deep into people's everyday lives. By choosing the tactic of school strike actions, they challenged school children to discuss with their teachers and parents about their motivation to participate. This created an instant intergenerational dialogue that created ownership on the topic across all ages. It is impossible to count the number of initiatives that spontaneously grew out of this awareness, and that stretched far beyond mere $\mathrm{CO}_{2}$ reduction, like local groups cleaning beaches, parks, and so on.

This heightened consciousness about the environment had a positive spillover effect on many companies. They decided to change their products and/or production processes to cut down $\mathrm{CO}_{2}$ emissions or reduce the use of plastics. This in turn stimulated start-up enterprises who took bold steps in developing environmentally friendly alternatives (like bamboo cups or cutlery).

At a political level, the movement had Greta Thunberg touring Europe (and in the autumn of 2019, USA and Canada) and giving her inspirational speeches everywhere. Greta Thunberg, Anuna De Wever Van der Heyden, Luisa Neubauer and some other youth leaders met privately with President Macron in Paris and met him again briefly, together with nine other heads of state, during an informal EU meeting in Romania in May. Again, firmly putting climate change on the top of the political agenda.

In the European elections of May, the green parties doubled their seats and together with other socialist political fractions they seem to be setting the stage to take huge steps forward in the next legislation. Obviously, this also meant that the topic of climate change was high on all political agendas worldwide. Raising it to the top of political priorities has also resulted in all parties formulating an opinion on the topic and taking a stand, generating a much belated but still highly needed public debate.

Locally, in each country we can also see huge wins that were generated by the school strike movement. For example, the panel of scientists that volunteered to write a climate action plan in Belgium. In some cities or countries, a climate emergency was declared as a direct result of the actions by the young people in collaboration with other climate organizations.

In short, it is impossible to overestimate the impact Greta Thunberg had when she decided to skip school on a Friday in September 2018, thereby showing the truth in cultural anthropologist Margaret Meads' saying: 'Never doubt that a small group of thoughtful, committed citizens can change the world; indeed, it's the only thing that ever has'. 


\section{NOTES}

1. This was said during a conversation with the authors in Rome, April 2019.

2. Lesbian, Gay, Transgender, Bisexual, Queer (or Questioning), Intersex. 